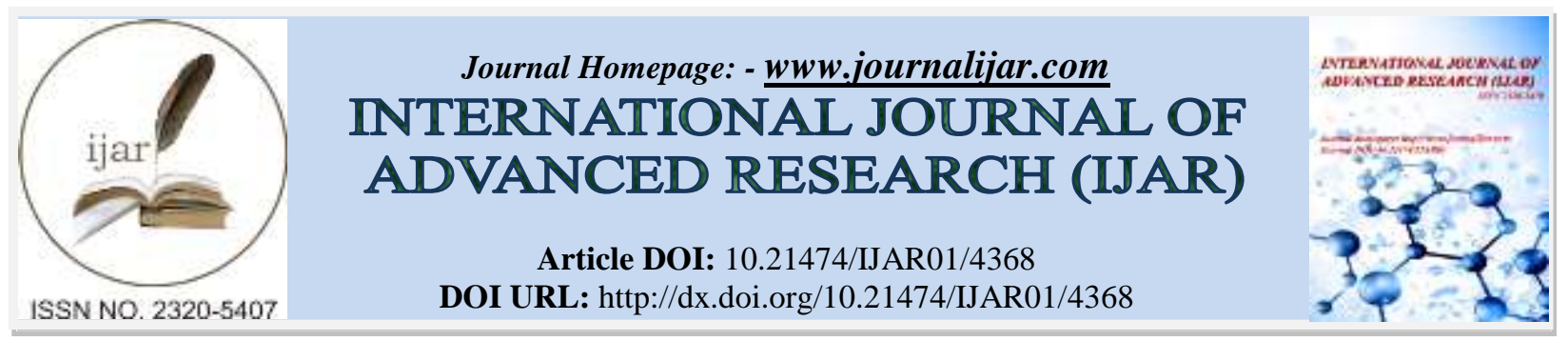

RESEARCH ARTICLE

\title{
INDUCTION OF BIOCHEMICAL CHANGES IN MOUSE TESTIS AFTER THE COMBINED TREATMENT OF RADIATION AND CADMIUM CHLORIDE.
}

\author{
C. L. Verma ${ }^{1}$ R. K. Purohit ${ }^{2}$ and M. L. Gupta ${ }^{3}$ \\ 1. Department of Zoology, Radiation Biology Laboratory, Govt. Lohia College Churu, India. \\ 2. Department of Zoology, Radiation Biology Laboratory, Govt. Dungar College Bikaner, India. \\ 3. Former Joint Director, College Education, Rajasthan, India.
}

\section{Manuscript Info}

\section{Manuscript History}

Received: 26 March 2017

Final Accepted: 28 April 2017

Published: May 2017

Key words:-

Radiation, Cadmium, Testis, Mice.

\section{Abstract}

Background: The main objective of the present investigation was to observe biochemical changes induced by radiation and cadmium individually as well as simultaneously on the testis of Swiss albino mice.

Materials and Methods: For this purpose, adult male Swiss albino mice (6-8 weeks old) were divided into four groups. Group I (shamirradiated), Group II (treated with $\mathrm{CdCl}_{2}$ solution $20 \mathrm{ppm}$ ), Group III (irradiated with 1.25, 2.5 and 5.0 Gy gamma rays), Group IV (both irradiated with $1.25,2.5$ and 5.0 Gy gamma rays and treated with $\mathrm{CdCl}_{2}$ solution). The animals were autopsied after $1,2,4,7,10,14$ and 28 days of treatment. The testis was taken out and different biochemical parameters, such as total proteins, DNA and RNA were estimated.

Results: It was found that contents of Total proteins, DNA and RNA decreased. Such decline was observed with higher dose $(5.00 \mathrm{~Gy})$ at early intervals. Recovery started at day 10 or 14 but control level could not be attained up to the last intervals. A similar decreasing pattern was observed with 2.5 and $1.25 \mathrm{~Gy}$, but it was found lesser as compared to 5.0 Gy group. The recovery was also faster in these groups. Results indicated the infliction of radiation insults and subsequent repair in the testes to be dose-dependent.

In combined treatment group the pattern of biochemical changes was similar to individual treatment but the magnitude of occurrence was statistically higher and the normal value could not be attained even at last autopsy (28 days). Thus the damage and recovery pattern in combined treatment (radiation and cadmium chloride) indicates the "synergistic" effect of these two agents.

Conclusion: These results indicate that combined treatment of cadmium and gamma radiation causes synergistic or additive effect.

Copy Right, IJAR, 2016,. All rights reserved.

\section{Introduction:-}

Every living being exposed to heavy metals and ionizing radiations since they are all natural components of our environments. A large numbers of studies have been done on all the risks associated with these agents. In today's 
world where there are numerous physical, chemical and biological agents in the environment, organisms are inevitably exposed simultaneously to a combination of such agents. Combined action of ionizing radiation and other agents are of potentially great importance because there are many occasions where interactions might occur in our environment. Testis is highly radiosensitive organ owing to their extremely active divisional status. As the continuing effects of radiation and cadmium exposure are primarily genetic, and fertility is the first to be adversely affected, and thus the effects to identify such damage is of prime importance. Those animals, which were treated with cadmium chloride and radiation both, show more damage as compared to individual one ${ }^{[1]}$.

Despite the large number of reports, there is scarcity of systemic data on the combined effects of environmental agents and ionizing radiation. Hence, it may be a field of great importance, which needs a further exploration of information. A supra-additive or additive type of synergism may be expected due to the combined use of radiation and cadmium.

The use of testis for study serves as a good model to assess the combined effects of toxicants. The testis is one of the most rapidly renewing tissues in the body and hence it responds rapidly to injury. Besides this, testis has valuable quantitative parameters as well as serially arranged qualitative configuration. In present study an attempt has been made to study the effects of ionizing radiations and cadmium individually and also their combined effect on testis of mouse.

\section{Materials and Methods:-}

Animals:-

Healthy male Swiss albino mice (6-8 weeks old) were procured from CCS Agricultural University, Hissar and maintained at $20-25^{\circ} \mathrm{C}$. The animals were housed in polypropylene cages and maintained on balanced mice feed and tap water ad libitum.

\section{Source of Radiation:-}

Cobalt gamma radiotherapy source (Theratron, AECL, Canada) was used to irradiate the animals. This facility was provided by the Radiotherapy Department of Prince Bijay Singh Memorial Hospital, Bikaner (Rajasthan), India. The animals were irradiated at the dose rate of $0.97 \mathrm{~Gy} / \mathrm{min}$.

\section{Cadmium chloride Treatment:-}

The aqueous solution of the cadmium chloride (SDS chemicals, India) was prepared by dissolving $20 \mathrm{mg}$ of cadmium chloride in $1000 \mathrm{ml}$ of the glass distilled water, thus giving a concentration of $20 \mathrm{ppm}$ and then administered orally in drinking water.

\section{Plan of experiment:-}

The animals were divided into different groups according to the treatment given to them:-

Group- I - Sham-irradiated animals serve as control.

Group- II - Only cadmium chloride treated animals.

Group- IIIa -1.25 Gy

Group- IIIb- $2.50 \mathrm{~Gy}$

Group- IIIc- $5.00 \mathrm{~Gy}$

Group- IVa- $\mathrm{CdCl}_{2}+1.25 \mathrm{~Gy}$

Group- IVb- $\mathrm{CdCl}_{2}+2.50 \mathrm{~Gy}$

Group- IVc- $\mathrm{CdCl}_{2}+5.0$ Gy

\section{Autopsy of Animals:-}

Five animals were autopsied by cervical dislocation from every set of experiment at each post-treatment interval of 1, 2, 4, 7, 1014 and 28 days. The weight of the animals was recorded and their testis was removed. The biochemical parameters studied were: Total proteins, DNA and RNA.

\section{Results and Discussion:-}

The changes in the total protein content of mice testes after treatment were recorded in this study (Figure -1). Animals of irradiated subgroups exhibited decrease in protein content upto day 2 in IIIa and upto day 4 in IIIb and IIIc. But increase in protein content was recorded on day 4 in IIIa and on day 7 in IIIb and IIIc. Then, the values 
lowered on day 7 in IIIa and day 10 in IIIb and IIIc subgroups. Further elevated level of protein content was noted from day 10 up to day 28 in IIIa and from day 14 upto day 28 in IIIb and IIIc subgroups. In group II, the values of total protein content decreased up to day 14 and then rose on day 28 . The changes in protein content pattern after combined exposure (group IV) were similar to those observed after irradiation but found to be more prominent as compared to that of respective irradiated subgroups.

DNA and RNA contents of the testes were found to decrease after irradiation upto day 4 in IIIa, upto day 7 in IIIb and upto day 10 in IIIc subgroups. Thereafter, the values increased up to day 28 in all the irradiated subgroups. In animals treated with $\mathrm{CdCl}_{2}$ (group II), the values of DNA decreased upto day 14 and then rose on day 28, whereas the values of RNA content decreased upto day 4 and then increased on day 7 and this increasing trend continued upto day 28. The changes in the value of DNA and RNA content after combined exposure (group IV) are almost same as observed after irradiation but found to be more prominent as compared to that of respective irradiated subgroups (Figure- 2 and 3). The decrease in total protein concentration on day 1 may be due to loss of activity of tissue protein as well as the reduced cell survival. Increase in protein concentration per gram tissue weight at day 7 (subgroup IIIb and IIIc) may be due to the elimination of most of the degenerated cells from the tissue and testicular weight thereof. Similar effects of irradiation and administration of cadmium chloride of protein concentration of mouse testis have been reported ${ }^{[2-3]}$.

The radiation dose depended depletion of DNA, as observed in the present investigation, has also been reported in the rat testis ${ }^{[4]}$. Decrease in DNA concentration is mainly attributed due to reduction in number of various germ cells causing loss in weight and shrinking of testis ${ }^{[5,6]}$ Cadmium causes inhibition of repair and replication system of DNA because of binding affinity with - SH group of enzymes. At later intervals, increase in RNA with increase doses could due to ability of DNA to transcribe RNA is not affected quantitatively ${ }^{[7-9]}$. or increase in nuclear RNA polymerase activity ${ }^{[10,11]}$. or enzyme for which RNA acts as substrate and destroyed by higher doses of irradiation ${ }^{[12]}$ A decrease in RNA was possibly brought about by impairment of both nucleic acid and protein synthesis.

Cadmium is quite enough for interaction with ionizing radiation, because it has high affinity for $-\mathrm{SH}$ and disulphide groups of protein ${ }^{[12]}$. Beside this, cadmium binds with thiol group of cellular components, which are mainly responsible for protecting repair system against damage caused by radiation-induced free radicals ${ }^{[13]}$. Due to indirect effects of irradiation, free radicals are formed which are scavenged by $-\mathrm{SH}$ group, an inherent protective mechanism present in the cells. When Cadmium is simultaneously added to radiation, these - SH groups are not available for protection because cadmium binds with them. Due to this, DNA is exposed to these free radicals and the risk increases during the combined exposure. The combined action of ionizing radiation and cadmium leads to increased DNA damage formation compared to the effects of the individual stressors. These results are consistent with a hypothesis that the presence of cadmium modulates the efficiency of DNA repair system thus causing increases in

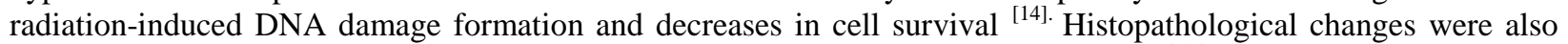
showed higher magnitude than individual exposure to radiation and cadmium chloride ${ }^{[15-17] .}$

In the present study, a synergistic/additive type of effect has been observed due to combined treatment of radiation and cadmium and its severity increased with the dose of radiation. Hence, the magnitude of depreciation was noted in the order of $\mathrm{CdCl}_{2}+5.0 \mathrm{~Gy}>\mathrm{CdCl}_{2}+2.50 \mathrm{~Gy}>\mathrm{CdCl}_{2}+1.25 \mathrm{~Gy}$ in the terms of total protein, DNA and RNA, in mouse testis. 


\section{Figure 1:-}

Changes in the values of total protein content $(\mathrm{mg} / \mathrm{gm}$ tissue wt.) in the testes of mice in various experimental groups.

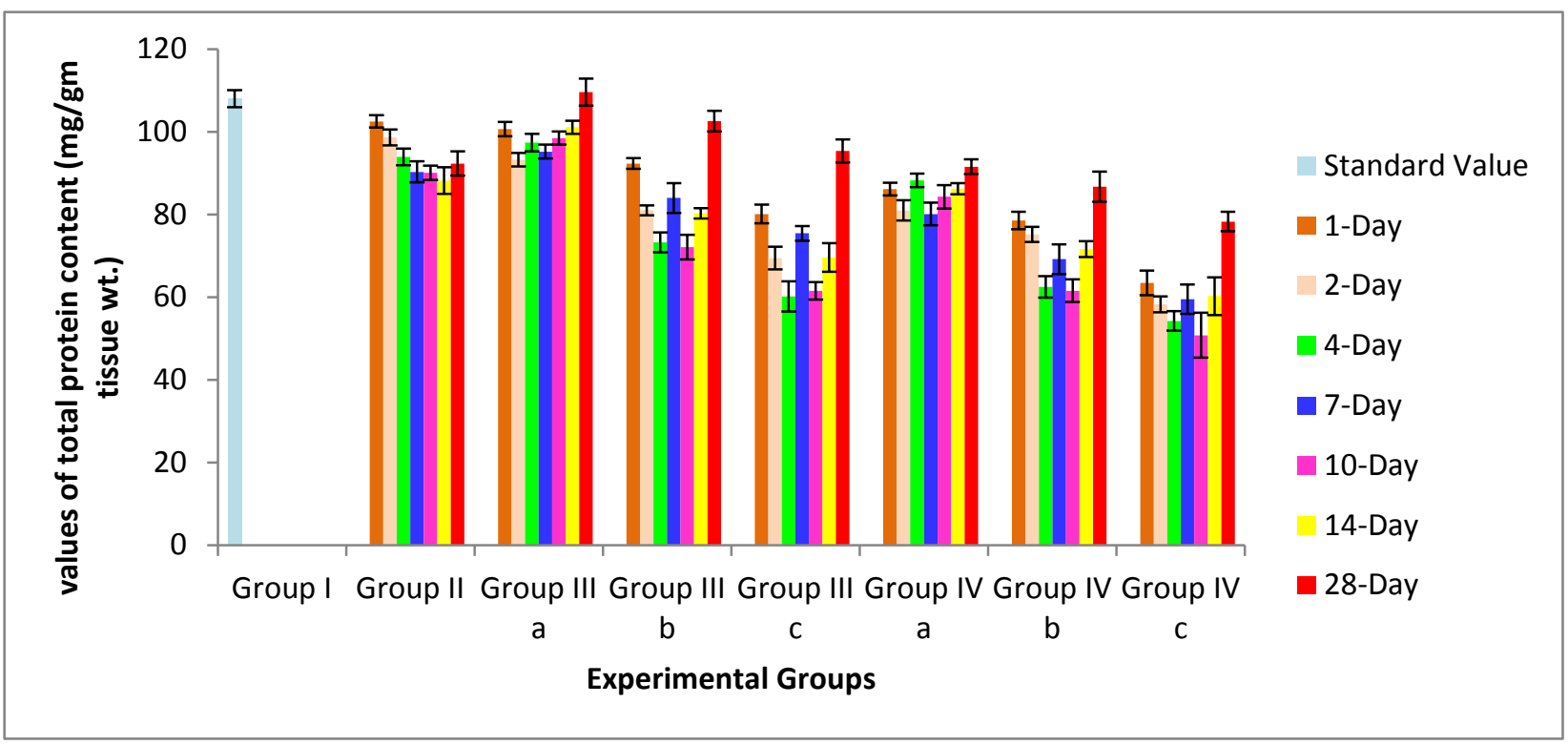

Figure 2:-

Changes in the values of DNA content (mg/gm tissue wt.) in the testes of mice in various experimental groups

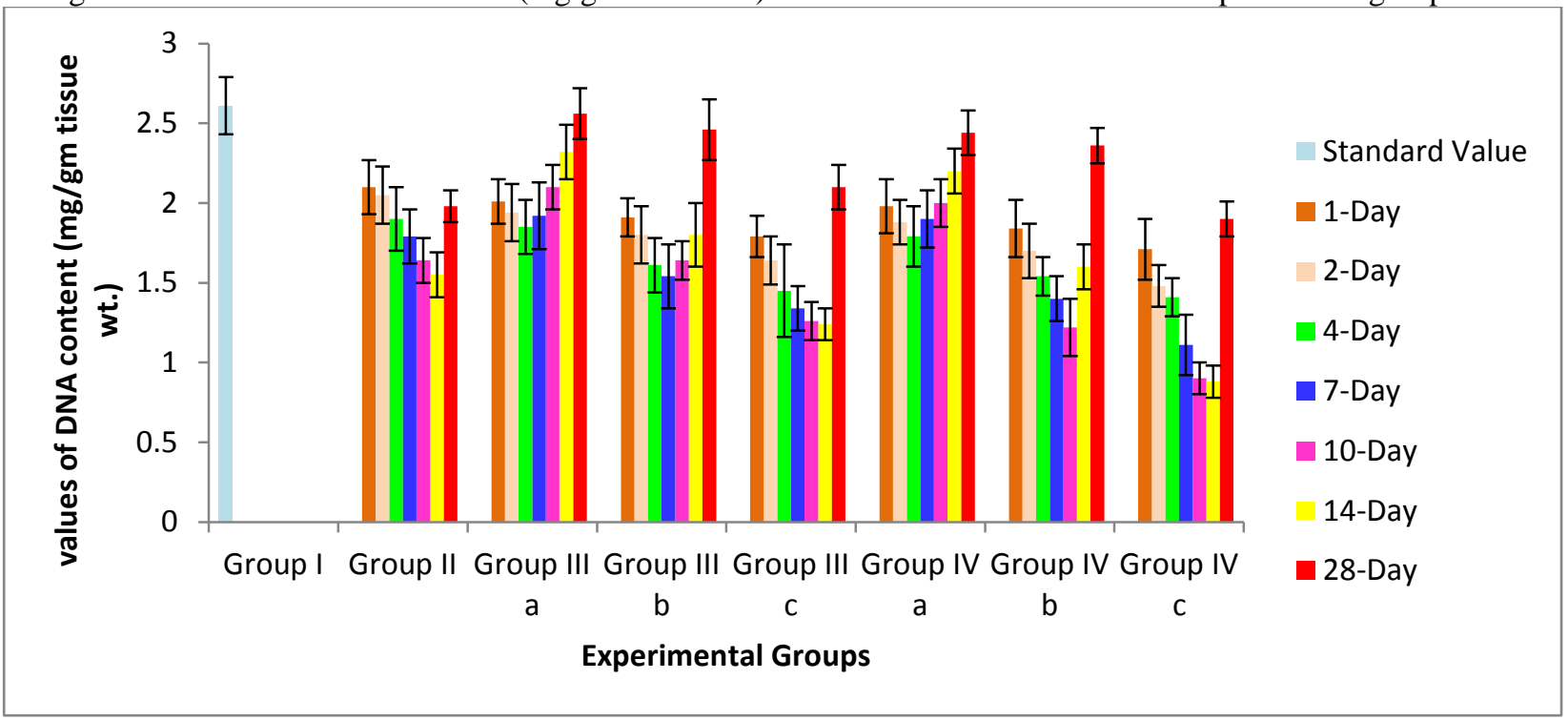


Figure 3:-

Changes in the values of RNA content (mg/gm tissue wt.) in the testes of mice in various experimental groups.

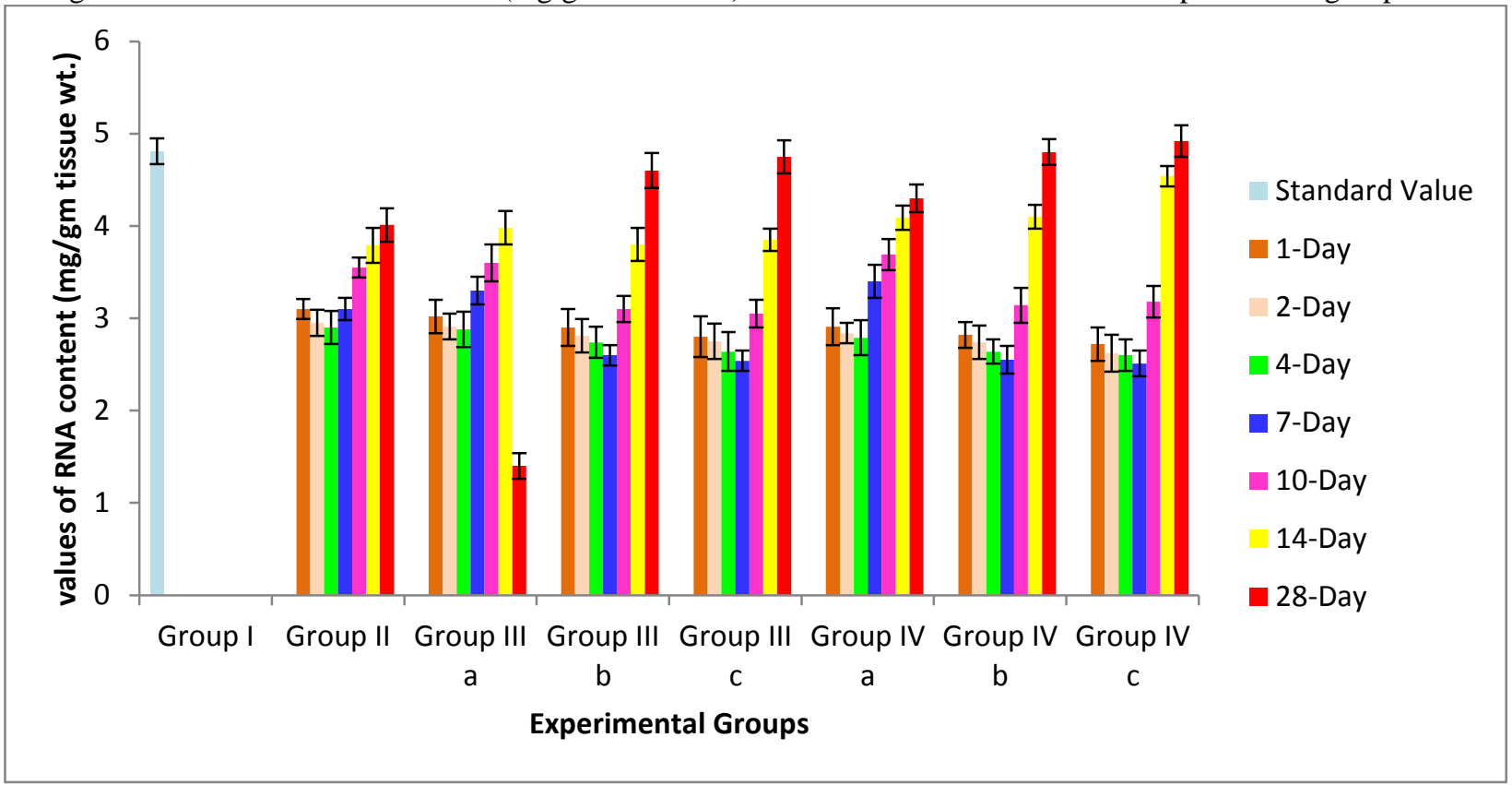

\section{Acknowlegment:-}

Authors gratefully acknowledge the facility provided by the Head, Department of Zoology and Principal, Govt. Lohia College Churu, India. The irradiation facility provided by the Department of Radiotherapy, PBM hospital Bikaner, India is also gratefully acknowledged.

\section{References:-}

1. Purohit, R.K., Chakrawarti, A. and Bhartiya, K.M. (2007): Radiation and cadmium induced biochemical alteration in mouse kidney. Iran. J. Radiat. Res., 5 (3): 125-130.

2. Bacq, Z.M. and Alexander, P. (1961): Fundamentals of radiobiology ( Pergamon Press Ltd, London).

3. Aoki, A. and Hoffer, A.P. (1978): Re-examination of the lesions in rat testis caused by cadmium. Biol. Reprod. , 18: 579.

4. Gupta, G.S. and Bawa, S.R. (1975a): Radiation effects on testes: IX. Studies on oxidative enzymes after partial body gamma irradiation. Strahlentherapie, 150: 158.

5. Nebel, B.R. and Murphy, C. J. (1960): Damage and recovery of mouse testis after $1000 \mathrm{r}$ acute localized xirradiation with reference to restitution cells, Sertoli cell increase and type A spermatogonial recovery. Radiat. Res., 12: 626.

6. Saharan, B.R. (1977): Studies on chemical radiation protection by 2-mercapto-propionyl glycine (MPG) on the testis of Swiss albino mice against external radiation. Ph.D. Thesis Submitted to the University of Rajasthan, Jaipur (India).

7. Hagen, U., Ullrich, M. and Jung, H. (1969): Transcription on irradiated DNA. Int. J. Rad. Biol., 16: 59.

8. Leon, S.A., Kollmann, G. and Shapiro, B. (973): Properties of DNA irradiated in the presence of protective agent bis (2-guanidiethyl) disulfide (GED). Int. J. Rad. Biol., 23: 285.

9. Leadon, S.A. and Ward, J.F. (1981): The effect of $\gamma$-irradiated DNA on the activity of DNA Polymerase. Radiat. Res., 86: 445.

10. Eldjarn, L. and Jellum, E. (1969): Studies on biochemical and radioprotective effects of thiols and disulphides at the sub-cellular and molecular level. In "Radiation damage and sulphydryl compounds". P. 45, IAEA, Vienna.

11. Hugon, J., Maisin, J.R. and Borgers, M. (1966): Delayed ultra-structural changes in duodenal crypts of irradiated mice. Int. J.Rad. Biol., 10: 113

12. Vallee, B.I. and Ulmer, D.D. (1972): Biochemical effect of mercury, cadmium and lead. Ann. Review of Biochem., 41: 91 
13. Muller, W.U., Streffer, C. and Fischer-Lahdo, C. (1985): Enhancement of radiation effects by mercury in preimplantation mouse embryos in vitro. Arch. Toxicol., 57: 114.

14. Grygoryev, D., Moskaleno, O. and Zimbrick, J. D. (2008): Non-Linear effects in the formation of DNA damage in Medaka fish fibroblast cells caused by combined action of cadium and ionizing radiation.Dose Response 6(3): 283-298

15. Verma, C. L., Purohit, R. K. and Gupta, M. L. (2009): Synergistic effect of radiation and cadmium chloride on mouse testis. Pharmacologyonline 1: 462-468.

16. Purohit, R. K., Seema, T., Chakrawarti, A. and Bhartiya, K. M. (2009) Protective role of aloe vera against radiation and cadmium chloride induced histopathological changes in the liver of Swiss albino mice. Pharmacologyonline 2: 595-604.

17. Bhardwaj, C., Gupta, M. L. and Naveen , K. (2012): Pathological alterations in the liver of Swiss albino mice induced by different degree of gamma radiation and cadmium chloride. Ind. j. of Veterinary Pathology. 36: 198-202. 